Wright State University

CORE Scholar

$1-2017$

\title{
Academic Librarians' Attitudes about Civic-Mindedness and Service Learning
}

Maureen Barry

Wright State University - Main Campus, maureen.barry@wright.edu

Laura A. Lowe

Sarah E. Twill

Wright State University - Main Campus, sarah.twill@wright.edu

Follow this and additional works at: https://corescholar.libraries.wright.edu/ul_pub

Part of the Information Literacy Commons

\section{Repository Citation}

Barry, M., Lowe, L. A., \& Twill, S. E. (2017). Academic Librarians' Attitudes about Civic-Mindedness and Service Learning. The Library Quarterly, $87(1)$.

https://corescholar.libraries.wright.edu/ul_pub/183

This Article is brought to you for free and open access by the University Libraries at CORE Scholar. It has been accepted for inclusion in University Libraries' Staff Publications by an authorized administrator of CORE Scholar. For more information, please contact library-corescholar@wright.edu. 


\title{
Academic Librarians' Attitudes about Civic-Mindedness and Service Learning
}

\author{
Maureen Barry, Laura A. Lowe, and Sarah Twill
}

\begin{abstract}
Although discourse on the civic engagement of libraries as institutions is plentiful, there has been little discussion of librarians as individuals. Librarianship is more than being a trustee of information. It includes responsibility for the common good. Libraries provide tools for education on social and political issues, but they can also collaborate in activities that improve well-being in their communities. Participating in service learning is one way that librarians on academic campuses can get involved. This study used a standardized scale to measure civic-mindedness among academic librarians and examine characteristics and activities, including service learning, related to variation in its scores. Results indicated that although most respondents made financial or service contributions, the group mean on the civic-mindedness scale was only moderate. Librarians who volunteered, had interest in service learning, or participated in community activities were more civic-minded than professionals who did not. Implications for the profession are discussed.
\end{abstract}

$n$ the early decades of the nineteenth century, when the United States was still in its infancy, Alexis de Tocqueville commented that "Americans of all ages, all conditions and all dispositions constantly unite" (2012, 896). He emphasized the uniqueness of average citizens initiating changes they saw as needed in society, rather than such action being limited to the elite. The United States was founded on this type of citizen participation and engagement with all levels of government as well as other community systems.

While we may have been joiners and doers at our nation's inception, the picture today is in stark contrast. The National Commission on Civic Renewal (1997) warned that we were in danger of becoming "a nation of spectators." Since then, numerous works, including Robert Putnam's famous book Bowling Alone, argue that this tragedy has now occurred, citing evidence such as historically low voter turnouts and sharp declines of participation in community groups to demonstrate that citizens are no longer engaged with creating change in our communities. The National Task Force on Civic Learning and Democratic Engagement (2012) made a national call for institutions of higher education to reclaim their role in producing active and engaged cit-

The three authors made equal contributions to this project and are listed in alphabetical order.

Library Quarterly: Information, Community, Policy, vol. 87, no. 1, pp. 1-16. (C) 2017 by The University of Chicago. All rights reserved. 0024-2519/2017/8701-0001\$10.00 
izens. There is no consensus within the literature as to the definitions of civic engagement or other engagement terms such as public involvement, community engagement, or public engagement (Adler and Goggin 2005; Driscoll, 2006). For the purpose of this research, we chose to use Thomas Ehrlich's definition of civic engagement: "working to make a difference in the civic life of our communities and developing the combination of knowledge, skills, values, and motivation to make that difference. It means promoting the quality of life in a community, through both political and non-political processes" (2000, vi). He goes on to note that "a morally and civically responsible individual recognizes himself or herself as a member of a larger social fabric and therefore considers social problems to be at least partly his or her own; such an individual is willing to see the moral and civic dimensions of issues, to make and justify informed moral and civic judgments, and to take action when appropriate" (2000, xxvi).

Julie Hatcher defines civic-minded professional as one who "is skillfully trained through formal education" and has "the ethical disposition as a social trustee" and "the capacity to work with others in a democratic way . . to achieve public good" $(2008,21)$. The concept of civicmindedness is a combination of one's personal and professional identities as well as the civic attitudes that influence and drive behaviors related to engagement (Hatcher 2008). Underlying the idea of a civic-minded professional is the philosophy that the educated have a responsibility to use their privileged position for the public good. One could argue that this is especially true of university graduates who attended institutions that are partially funded by taxpayer dollars, those who receive Pell Grants or Stafford Loans, or those who receive any scholarship funds given as part of a private citizen's philanthropic deeds. Graduates who are civically minded "pay it back" to the aforementioned through civic participation, but they also "pay it forward" by creating opportunities for the next generation of scholars.

\section{Libraries and Civic Engagement}

Do libraries have a role to fulfill in civic engagement? The American Library Association (ALA) seems to suggest that the answer is yes, stating that libraries and librarians have a part to play in "ameliorating or solving the critical problems of society ... [and] help[ing] inform and educate the people of the United States on these problems" (American Library Association 2013a, A.1.1). The ALA has a long and rich history of fostering a sense of responsibility in librarians to provide the tools citizens need to thoughtfully participate in society (Raber 2007), and many authors have reinforced this idea of duty to society (Kranich 2000; McCook 2000; McCabe 2001).

Lee Finks states that the values of "service, commitment to truth-seeking and intellectual freedom, and a sense of responsibility" among librarians "are inherent in librarianship and its function in society" $(1989,352)$. Michael Gorman similarly argues that libraries are integral to the functioning of a democracy: "All values and ideas that dominate library discourse and practice are democratic values and ideas-intellectual freedom, the common good, service to all, the transmission of the human record to future generations, free access to knowledge 
and information, nondiscrimination, and so on. . . Libraries have grown and flourished in the soil of democracy, and our fate is inextricably intertwined with the fate of democracy" (2000, 160).

The ALA (2008) postulates that an informed citizenry is the foundation of a political system; within that system, libraries promote information sharing necessary to a democracy. Equal access to information appears to be the basis of librarians' ethical code. John Budd comments that the "essential character of ethics in librarianship includes recognition that, as a profession, the concern is for the public life of participants and their public actions" (2006, 252). Kathleen McCook (2000) suggests that libraries are central to the civic life of a community. She further notes examples of how libraries can do or are doing more to provide patrons with access to knowledge and tools to increase their level of civic participation.

Ronald McCabe calls "for library users to be treated as community partners" and "for public libraries to be active problem-solving agencies working in collaboration with other community organizations and individuals to improve community life" (2001, 111). There are numerous examples of public libraries reaching out to underserved populations (McCook 2000; Alexander 2008; Adeyemon 2009; Gehner 2010; Bishop and Veil 2013; Morris 2013). While identifying underserved populations does likely increase opportunities for civic participation by diverse populations, it appears to move beyond freedom of information and access to services for all. McCook (2000) calls these examples "community building" and suggests that libraries have a vital part to play in such initiatives. Others suggest that these types of efforts are part of the "Civic Library" (Schull 2004) or "civic librarianship" (McCabe 2001).

\section{Academic Libraries and Civic Engagement}

Where does the academic library fit within the broader context of civic engagement in higher education? First, it is necessary to establish the current landscape of civic engagement of higher education so that efforts by academic libraries can be situated within that context. Several national organizations and associations are dedicated to renewing the civic purposes of higher education. For example, a Campus Compact report (Boyte and Hollander 1999) called for academic institutions to initiate and maintain long-term relationships with communities, including K-12 schools and other civic organizations. The National Task Force on Civic Learning and Democratic Engagement articulated the need to "[invest] on a massive scale in higher education's capacity to renew this nation's social, intellectual and civic capital” (2012, 2).

Academic libraries exist, first and foremost, to serve the faculty, staff, and students at their institutions. However, Nancy Courtney (2009) challenges academic libraries to create unique opportunities to support their institutions' community engagement efforts. While Lynn Westney (2006) suggests that academic libraries have been largely absent from the conversation, academic libraries have contributed to engagement efforts in a variety of ways, including partnering with city government or public libraries to meet the surrounding community's needs (e.g. Collins, 
Howard, and Miraflor 2009; Vander Broek and Rodgers 2015), supporting service-learning courses (e.g., Herther 2008; Nutefall 2009; Barry 2011a, 2011b), initiating deliberative discussions about democracy (e.g., Kranich, Reid, and Willingham 2004), partnering with cooperative extensions (Faiks 2002), and publishing via open-access methods (Shuler 2007). While the academic library engagement literature is broad, and much of it focuses on campus engagement (Salinero and Beardsley 2009; Franklin 2012; Kranich, Lotts, and Springs 2014) or student engagement (Snavely 2012; Scull 2014) - including how libraries contribute to student learning (Kuh and Gonyea 2015; Oakleaf 2015), student retention (Clink 2015; Murray 2015), and student success (Crowe 2015; Nichols Hess et al. 2015) - the authors of this article seek to contribute to the growing body of literature about the role of academic libraries in civic engagement.

\section{Service Learning}

There are a variety of methods for academic libraries to engage with the campus community and its surroundings, many of which were mentioned in the previous section. In addition to the aforementioned engagement strategies, service-learning pedagogy can help librarians engage with both the campus community and the surrounding community. Service learning is "a credit-bearing educational experience in which students participate in an organized service activity that meets identified community needs and reflect on the service activity in such a way as to gain further understanding of course content, a broader appreciation of the discipline, and an enhanced sense of civic responsibility" (Bringle and Hatcher 1996, 222). Academic librarians have begun to explore service learning's place in the library (Riddle 2003; Herther 2008; Heiselt and Wolverton 2009; Nutefall 2009; Barry 2011a, 2011b, 2011C; Hall 2012). Westney argues for the inclusion of service learning, stating that it "fosters the development of awareness, empathy, personal values and beliefs, self-confidence, self-esteem, and social responsibility while helping to foster a sense of caring for others" (2006, 202). Mary Ball suggests that to "a greater degree than fieldwork, service learning emphasizes the development of values and students' identification as civically engaged professionals" (2008, 72).

While service learning is just one type of engagement pedagogy, it seems to be a method of choice in many 4-year institutions (National Task Force on Civic Learning and Democratic Engagement 2012). Ashley Finley writes that half of students in college have participated in a service learning course and that "dozens of studies show that service-learning is positively associated with a variety of civic learning outcomes" $(2012,1)$. Perhaps this is because "full civic literacies cannot be garnered only by studying books: democratic knowledge and capabilities also are honed through hands-on, face-to-face, active engagement in the midst of differing perspectives about how to address common problems that affect the well-being of the nation and the world" (National Task Force on Civic Learning and Democratic Engagement 2012, 3). Consequently, service learning is the main method of library engagement investigated by the researchers. 


\section{Librarians as Civic-Minded Professionals}

McCook suggests that some community-building efforts "transcend the everyday approach to work" $(2000,69)$ in libraries, and she argues that "the need for librarians to be involved as citizens in their communities is of growing importance" (69). It seems unlikely that the objective of libraries to be integrally engaged with their communities can be achieved without considering the individual ideologies of librarians themselves. Our study sought to begin exploring librarians' attitudes and behaviors related to engagement with their communities. Further, the authors were interested in whether librarians involved with service learning had different views of civic responsibility.

The authors used the civic-minded professional (CMP) scale to measure civic-mindedness among academic librarians. While the term civic professional dates as far back as John Dewey (1927), the definition that most closely fits the purposes of this study is one that Hatcher (2008) used while developing the CMP scale. Hatcher suggests that a person who "is skillfully trained through formal education" and has "the ethical disposition as a social trustee" as well as "the capacity to work with others in a democratic way . . to achieve public good" (2008, 21) can be identified as a civic-minded professional. Civic-mindedness exists in the overlap between self-identity; one's work, career, and profession; and civic attitudes and actions (Hatcher 2008). Hatcher endeavors to quantify that intersection with the CMP scale, which asks for beliefs about voluntary action, professional identity and calling, citizenship responsibilities, being a social trustee, and consensus building.

\section{Methods}

The researchers were interested in learning how librarians view civic-mindedness. Of particular interest was whether academic librarians who engaged in service learning or other civic-minded pedagogies as part of their roles differed from librarians who did not. The researchers were interested in how civic-mindedness might differ among groups of librarians, such as by type of institution, role within the library, and years of service.

The Institutional Review Board at the first and third authors' university granted permission to conduct research. Survey data were collected from librarians between March 21 and May 1, 2014. Participants were contacted via e-mail and asked to complete an online questionnaire, gave implied consent when they opened the survey, and were provided with information on how to obtain study results.

Participants were recruited from professional Listservs hosted by ALA and the Academic Library Association of Ohio. The first e-mail was sent on March 21, 2014, and a follow-up e-mail was sent a few weeks later. To increase participation, participants were encouraged to share the e-mail with colleagues.

Qualtrics, a web-based survey service, was utilized to collect responses. The researchers estimated that it took 15 minutes to complete the survey. Participants answered a maximum of 
71 questions. Items were primarily closed-ended questions with a list of forced-choice responses. In order to assess attitudinal items, a Likert scale was used with seven options ranging from "strongly agree" to "strongly disagree." Participants were asked to respond to 44 questions about civic-mindedness, the dependent variable. Demographic information was collected as well as information about participation in activities such as volunteering, donating money to charitable organizations, and involvement in professional library organizations. Based on a participant's status (e.g., a librarian who had teaching responsibilities versus one who did not interact with students), the respondents received follow-up questions specific to their qualifying response (e.g., nature of contributions and length of time involved with service learning).

A modified version of Hatcher's CMP scale was used for this study; 44 items were included, and the scale demonstrated good reliability (Cronbach's alpha $=.937$ ) in the sample. CMP scores could theoretically range from 44 to 308 .

Statistical analysis was conducted using SPSS Statistics version 21 for Mac. An alpha of .05 was used for statistical tests. For the 311 respondents who completed enough of the survey to be included, missing responses on the CMP items were replaced with the series mean. Four cases with extreme scores on the CMP scale (more than 12 points higher than the next-highest scores) were dropped.

\section{Results}

The final sample was made up of 307 respondents. As can be seen in table 1, the majority of the sample was female and white. Respondents were evenly distributed across age groups. Half of the sample had less than 11 years of experience as a librarian. The great majority of degrees were in library science and at the master's level. Respondents reported that their jobs included reference and/or instruction (57\%), while 15\% selected administration as their primary job function. More respondents were employed by research universities or master's-level institutions than by 4-year institutions or community colleges. More respondents were from Ohio

$(n=67)$, but 42 other states were represented, and 13 respondents lived outside the continental United States.

\section{Interest in Service Learning}

Respondents were asked about experience with or interest in service learning. Twenty-four of the librarians ( $8 \%$ ) said that they did not know, and 83 (28\%) had been involved with service learning. Fifty-four (18\%) had never been involved with service learning but were interested in related activities, including teaching a for-credit information literacy course with service learning (22\%), providing library instruction (30\%), creating a research guide for a course (54\%), creating a general service-learning research guide (41\%), scheduling individual research appointments with service-learning students (35\%), purchasing library materials (48\%), exploring partnership or an embedded librarian position for a service-learning course (54\%), publishing 
Table 1. Sample Demographics

\begin{tabular}{|c|c|}
\hline Variable & $\%$ \\
\hline \multicolumn{2}{|l|}{ Gender $(N=290)$ : } \\
\hline Male & 17.2 \\
\hline Female & 82.8 \\
\hline \multicolumn{2}{|c|}{ Minority status $(N=291)$ : } \\
\hline White & 91.4 \\
\hline Nonwhite & 8.6 \\
\hline \multicolumn{2}{|c|}{ Long-term relationship $(N=288)$ : } \\
\hline Yes & 65.0 \\
\hline No & 35.0 \\
\hline \multicolumn{2}{|c|}{ Coresident children $(N=291)$ : } \\
\hline Yes & 22.7 \\
\hline No & 77.3 \\
\hline \multicolumn{2}{|l|}{ Age $(N=291)$ : } \\
\hline $21-30$ & 15.1 \\
\hline $31-40$ & 24.4 \\
\hline $41-50$ & 23.4 \\
\hline $51-60$ & 24.1 \\
\hline $60+$ & 13.1 \\
\hline \multicolumn{2}{|c|}{ Years of experience $(N=292)$ : } \\
\hline 2 or less & 13.0 \\
\hline $3-5$ & 17.1 \\
\hline $6-10$ & 18.5 \\
\hline $11-15$ & 14.4 \\
\hline $16-20$ & 9.6 \\
\hline $21-25$ & 8.2 \\
\hline $26+$ & 19.2 \\
\hline \multicolumn{2}{|c|}{ Type of institution $(N=286)$ : } \\
\hline Community college & 16.0 \\
\hline Four-year college & 17.7 \\
\hline Master's level & 25.9 \\
\hline Doctoral level & 37.8 \\
\hline \multicolumn{2}{|c|}{ Size of institution $(N=295)$ : } \\
\hline Less than 5,000 & 36.9 \\
\hline $5,000-15,000$ & 30.5 \\
\hline More than 15,000 & 32.5 \\
\hline
\end{tabular}

about service learning $(7 \%)$, presenting at conference about service learning ( $9 \%)$, or other plans ( $9 \%)$.

The largest group (46\%) had no experience with or interest in service learning. These 138 librarians were asked what prevented them from participating. The most frequently endorsed explanation was that they had never been asked (62\%), but other reasons were also noted, including that they did not know what service learning was (2\%), they never thought about it (20\%), time constraints $(44 \%)$, or lack of support from administration (13\%). Finally, most respondents were unaware (30.7\%) or believed their library had never been a community part- 
ner in a service-learning project (57.3\%). Fifty-three percent reported that their universities had a service-learning office on campus.

\section{Engagement with the Community}

About $11 \%$ of respondents believed their obligation to donate money to charitable organizations is carried out through their employment as a librarian. Most respondents (97\%) reported some charitable financial contributions; however, of those, only $30 \%$ gave more than $\$ 1,000$ per year.

More respondents $(\sim 39 \%)$ believed that their obligation to volunteer was fulfilled through employment. Nevertheless, about 47\% were current volunteers, and almost all of the rest reported volunteering in the past. Of those respondents who either strongly agreed or agreed that their obligation to volunteer was met through their job, 63.2\% reported that they were currently volunteering. Of those respondents who strongly disagreed or disagreed with that idea, $47 \%$ were current volunteers. Looking at this a different way, 30\% of the current volunteers strongly agreed or agreed that their employment met their volunteer obligation, and $27 \%$ strongly disagreed or disagreed. The librarians reported volunteering in different types of settings but most frequently indicated religious (16\%), educational (15\%), civic or community (12\%), professional associations $(16 \%)$, or cultural (14\%) settings. Only two respondents had never volunteered.

\section{Civic-Mindedness}

The CMP scale score was calculated for the 307 respondents. The scale's possible scores ranged from 44 to 308. Higher scores on the scale indicate lower civic-mindedness. The minimum achieved score was 49 (more civic-minded), and the maximum was 188 (less civic-minded). The mean score was $144.7(\mathrm{SD}=28.2)$.

No differences in CMP scores were indicated when comparing male to female or white to nonwhite respondents. Being in a long-term relationship, having coresiding children, years of experience as a librarian, nature of institution, or size of student body did not appear to have any relationship with CMP scores. However, it should be noted that some of the comparisons included groups of very unequal sizes.

According to an ANOVA analysis, there did appear to be some, though minimal, difference in CMP scores based on age $[\mathrm{F}(4,286)=3.6, p=.008]$. The only significant post hoc comparison was between the 31-40 age group and the over-6o group. Other comparisons (31-40 vs. $61+, 41-50$ vs. $61+$, and 31-40 vs. 51-60) approached significance.

Another ANOVA analysis indicated that civic-mindedness did significantly differ based on participation or interest in service learning $[\mathrm{F}(3,295)=7.1, p=.000]$. Figure 1 displays the mean plot. As can be seen, those librarians who had participated in service learning were the most civic-minded. Post hoc comparisons indicated that this group of respondents was significantly more civic-minded than those who expressed no interest. 


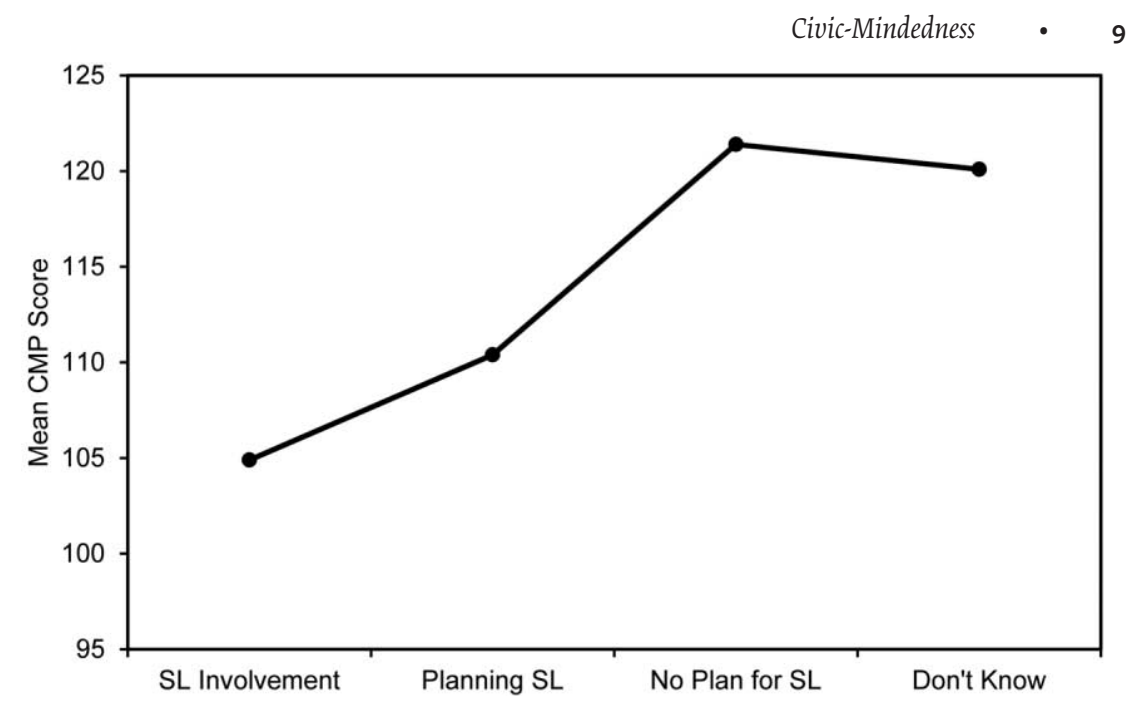

Figure 1. Plot of mean CMP scores by interest in service learning

Size of charity donations does not appear to be related to CMP scores in our sample either. However, a significant independent sample $t$-test $[t(297)=-5.1, p=.000]$ indicated that current volunteers were more civic-minded $(M=106.3, S D=28.2)$ than previous volunteers $(M=$ 122.2, $\mathrm{SD}=26.0$ ).

Respondents were also asked how often they participated in 10 different community activities, measured on a 4-point scale from "never" (scored as 1) to "frequently" (scored as 4). ANOVA analyses indicated that there was not a significant connection between how often respondents participated in religious activities and civic-mindedness; however, significant tests were seen with all the other activity variables (see table 2). Mean plots indicated linear relationships in each case.

Table 2. ANOVA of Activities on CMP Scores

\begin{tabular}{llcrl}
\hline Variable & $M(S D)$ & $N$ & $F$ & $P$ \\
\hline Assisted a service-learning class & $1.9(.95)$ & 301 & 13.66 & .000 \\
Collaborative research in community & $1.6(.88)$ & 302 & 16.85 & .000 \\
Provided service in community & $2.1(1.3)$ & 302 & 20.37 & .000 \\
Gave a talk in community & $1.7(.88)$ & 301 & 13.93 & .000 \\
Civic-minded materials in class & $1.8(.98)$ & 302 & 21.60 & .000 \\
Pro bono services to community & $1.9(1.09)$ & 300 & 18.54 & .000 \\
Participated in service event & $2.4(1.04)$ & 302 & 18.07 & .000 \\
Volunteered in community & $2.8(1.17)$ & 302 & 9.48 & .000 \\
Attended religious services & $2.4(1.27)$ & 301 & .84 & .472 \\
Politically active & $3.3(.83)$ & 301 & 11.52 & .000 \\
& & & & \\
\hline
\end{tabular}


Finally, a stepwise regression analysis was conducted to explore how much of the variance in CMP scores could be explained by the variables that had been identified as having a relationship with civic-mindedness. Age, nine different civic activities, volunteer status, and service-learning interest were all input as variables to be considered. None of these variables indicated a problem with collinearity (tolerance was $>.1$ ). The analysis resulted in a final model with five variables able to predict about $36 \%$ of the variation in CMP scores $[F(1,253)=$ 29.69, $p=.000$ ]. The effect size $(r=.61)$ was large. Table 3 displays the model summaries and coefficients.

\section{Discussion}

The purpose of this study was to describe the characteristics of civic-mindedness among academic librarians. The sample mean on the CMP scale indicated moderate civic-mindedness as a group. Most of the sample reported making contributions to the community through charity donation and/or volunteer service. While few differences in civic-mindedness were found when comparing demographic groups, other characteristics did indicate differentiation. Librarians who were current volunteers, had involvement with or interest in service learning, or were involved in a variety of community activities (other than religious services) showed higher levels of civic-mindedness. Specifically, being a board member in the community, using civic-minded materials in the classroom, participating in political activities, providing pro bono or reducedrate services, and having an interest in service learning all contributed significantly to CMP scores, explaining about $36 \%$ of the variation.

The authors were particularly interested in the connection between civic-mindedness and experience with service learning. Our sample had little involvement with service learning and

Table 3. Stepwise Regression Model Summaries and Coefficients for Final Model

\begin{tabular}{|c|c|c|c|c|c|c|c|}
\hline Model & $R$ & $R^{2}$ & Adj. $R^{2}$ & $\Delta$ in $R^{2}$ & $F_{\text {chg }}$ & $p$ & $\mathrm{df}_{1}, \mathrm{df}_{2}$ \\
\hline 1 & .414 & .172 & .168 & .172 & 53.24 & .000 & 1,257 \\
\hline 2 & .543 & .295 & .290 & .124 & 44.86 & .000 & 1,256 \\
\hline 3 & .573 & .328 & .320 & .033 & 12.52 & .000 & 1,255 \\
\hline 4 & .593 & .352 & .341 & .023 & 9.19 & .003 & 1,254 \\
\hline 5 & .608 & .370 & .357 & .018 & 7.33 & .007 & 1,253 \\
\hline \multicolumn{3}{|c|}{ Final Model Variables } & $B$ & $\beta$ & $t$ & Bivariate $r$ & Partial $r$ \\
\hline \multicolumn{3}{|c|}{ Board member } & -5.15 & -.25 & -4.29 & -.41 & -.21 \\
\hline \multicolumn{3}{|c|}{ Civic-minded materials } & -6.95 & -.26 & -4.71 & -.41 & -.24 \\
\hline \multicolumn{3}{|c|}{ Politically active } & -5.49 & -.17 & -3.28 & -.30 & -.16 \\
\hline \multicolumn{3}{|c|}{ Pro bono services } & -4.61 & -.19 & -3.28 & -.39 & -.16 \\
\hline \multicolumn{3}{|c|}{ Service-learning interest } & 7.54 & .14 & 2.71 & .28 & .13 \\
\hline
\end{tabular}


expressed relatively little interest. While as a whole they scored in the moderate range on the CMP scale, librarians with interest in or experience with service learning were significantly more civic-minded. One reason for the lack of involvement in service learning may be lack of exposure. Robert Bringle and Julie Hatcher (1996) discuss campuses' need for an office of service learning. They argue that in order for institutional efforts to be successful, these offices must gain the interest of faculty in service learning and provide them with the support needed to implement service learning in their courses. While many universities have implemented this suggestion ( $53 \%$ of our sample), it appears that librarians may not have been included in these offices' efforts. A significant number of librarians did not know anything about service learning, had never been asked to be involved, and felt little support from administration to do so.

\section{Implications}

The American Library Association, the largest professional organization of librarians, identifies eight key action areas that guide the strategic plan and resources (American Library Association 2013b). Three of the eight areas have philosophical and practical ties to ideas of civic-mindedness, including Advocacy for Libraries and the Profession, Diversity, and Equitable Access to Information and Library Services. The ALA calls for specific action in these areas.

In addition, ALA (American Library Association 2006, 2012b) supports roundtables that address issues related to diversity and equitable access such as the Ethnic and Multicultural Information Exchange Round Table; the Gay, Lesbian, Bisexual, and Transgendered Round Table; and the Social Responsibilities Round Table. The Social Responsibilities Round Table has a Hunger, Homelessness, and Poverty Task Force committed to understanding these social issues and assuring that the poor have access to and can use libraries (American Library Association 2012a). Despite these aspirations, special task forces, and committees, our results indicate only moderate civic-mindedness among the academic membership. This might suggest a disconnect between the profession's organization and members on the front line of patron services. Having said that, the data suggest that librarians care about engagement with their community. Forty-seven percent of respondents were current volunteers, and 97\% gave money to charitable causes. The mean score on the CMP scale was 144.7, placing it in the middle of the scale in terms of civicmindedness. What is not known is whether librarians are more or less civically minded than other professionals; comparison to other groups is a next step in understanding of the topic. Nevertheless, given ALA's emphasis on public engagement, librarians could be doing more to "be active problem-solving agencies working in collaboration with other community organizations and individuals to improve community life" (McCabe 2001, 111).

\section{The Role of Library Administrators}

Academic librarians must show how they contribute to their institution's mission (Oakleaf 2010). Some of the reasons academic librarians cite for not participating in service-learning courses 
are lack of time or lack of support from administration. Because service-learning courses impact the community and in many cases support the institution's mission, librarians who use this pedagogy are simultaneously furthering the civic mission of libraries, thereby upholding the values of the profession while fulfilling their obligation to the university community. Library administrators should consider this point when creating strategic plans and evaluating instruction programs. When assessing library instruction programs, administrators can highlight efforts that contribute to the community through service learning. The data collected have the potential to bolster the libraries' value to stakeholders in both the community and the academy.

Academic librarians' attitudes about civic engagement have substantial consequences for the profession. Those in leadership positions can play significant roles in the library's civic mission by initiating or supporting engagement efforts. The Libraries Transforming Communities (American Library Association 2013c) campaign provides resources that help all libraries engage with the community.

\section{Limitations}

This study had some design and measurement limitations. Probably the most significant of the design limitations is temporal priority. While the prediction model was successful in explaining a large proportion of the variance in CMP scale scores, the researchers cannot determine whether civic-mindedness influences behavior or behavior influences civic-mindedness. So while it seems clear that civic-mindedness is related to the identified activities, it is not known whether participating in community activities builds civic-mindedness or civic-minded professionals are more likely to participate in community activities.

It is also possible that respondents gave socially desirable answers. Those interested in the topic may have been more likely to respond to the survey, a problem of self-selection bias, particularly since the sample was nonrandom. However, given that nearly half of the sample indicated no interest in service learning, this threat appears limited.

\section{Future Research}

It is possible that this study's focus on academic librarians as participants may represent only a certain segment of librarians. That is, are academic librarians more or less civically minded than their public librarian counterparts, given the constituents they serve? Does spending time with the educated elite rather than the users of the public library, some of whom use the library because they lack the financial resources to afford books, computers, or access to the Internet, make academic librarians more or less in tune with civic issues? Future research might survey librarians in a variety of settings-public libraries in particular-and compare them to this sample of academic librarians.

Finally, it is unknown how this sample of librarians compares to other professionals. Obtaining the data from Hatcher (2008) and Twill and Lowe (2014) may provide a more complex 
analysis and context in which to assign meaning of the CMP scale scores. It may also be interesting to compare librarians to other similar helping professionals to examine similarities and differences in civic-mindedness.

\section{Conclusion}

Librarians have a long history and a professional mandate through ALA to provide for the public good by making sure that patrons have the access and opportunity to use information. The ALA takes a number of positions that affirm the importance of librarians' role in helping "solve social problems and inequities in order to carry out their mandate to work for the common good and bolster democracy" (American Library Association 2012b). The nature of librarians' work puts them in constant contact with the public, thus positioning them to be change agents in society. However, in this study, academic librarians had only moderate CMP scale scores. Those with an interest in or experience with service learning were significantly more civic-minded, suggesting an opportunity for university and library administrators, the professional library staff they employ, and ALA to consider ways to enrich librarians' commitment to contributing to the civic life of a community in the twenty-first century.

\section{References}

Adeyemon, Earnestine. 2009. "Integrating Digital Literacies into Outreach Services for Underserved Youth Populations." Reference Librarian 50 (1): 85-98.

Adler, Richard P., and Judy Goggin. 2005. "What Do We Mean by 'Civic Engagement'?” Journal of Transformative Education $3(3): 236-53$.

Alexander, Otis D. 2008. "Public Library Services to Underrepresented Groups: Poor and Unemployed, Emphasizing Danville, Virginia." Public Library Quarterly 27 (2): 111-33.

American Library Association. 2006. "Round Tables.” www.ala.org/groups/rts.

American Library Association. 2008. "Code of Ethics of the American Library Association." http://www .ifmanual.org/codeethics.

American Library Association. 2012a. "Hunger, Homelessness, and Poverty Task Force." http://www.ala .org/srrt.

American Library Association. 2012b. "Social Responsibilities Round Table." http://www.ala.org/srrt.

American Library Association. 2013a. "ALA Policy Manual Section A: Organization and Operational Policies.” http://www.ala.org/aboutala/sites/ala.org.aboutala/files/content/governance/policymanual /Links/cd_10_1_Section\%20A\%20New\%20Policy\%20Manual-1\%20\%28final\%2011-30-2015\%29\%2owith $\% 20$ TOC\%29.pdf.

American Library Association. 2013b. "About ALA." www.ala.org/aboutala.

American Library Association. 2013c. "Libraries Transforming Communities.” www.ala.org/transforminglibraries /libraries-transforming-communities.

Ball, Mary Alice. 2008. "Practicums and Service Learning in LIS Education." Journal of Education for Library and Information Science 49 (1): 70-82.

Barry, Maureen. 2011a. "Librarians as Partners in Service-Learning Courses (Part I).” LOEX Quarterly 38 (1): 8-10. Barry, Maureen. 2011b. "Librarians as Partners in Service-Learning Courses (Part II)." LOEX Quarterly 38 (2): $8-10$. 


\section{The Library Quarterly}

Barry, Maureen. 2011c. "Research for the Greater Good: Incorporating Service-Learning in an Information Literacy Course at Wright State University." College and Research Libraries News 72 (6): 345-48.

Bishop, Bradley Wade, and Shari R. Veil. 2013. "Public Libraries as Post-Crisis Information Hubs." Public Library Quarterly $32(1): 33-45$.

Boyte, Harry, and Elizabeth Hollander. 1999. "Wingspread Declaration on Renewing the Civic Mission of the American Research University.” Campus Compact. http://compact.org/wingspread-declaration-on -the-civic-responsibilities-of-research-universities.

Bringle, Robert G., and Julie A. Hatcher. 1996. “Implementing Service Learning in Higher Education.” Journal of Higher Education 67 (2): 221-39.

Budd, John M. 2006. “Toward a Practical and Normative Ethics for Librarianship.” Library Quarterly 76 (3): 251-69.

Clink, Kellian D. 2015. “The Academic Library's Role in Student Retention.” PNLA Quarterly 80 (1): $20-24$.

Collins, Lynda N., Francis Howard, and Angie Miraflor. 2009. "Addressing the Needs of the Homeless: A San Jose Library Partnership Approach.” Reference Librarian 50 (1): 109-16.

Courtney, Nancy. 2009. "Breaking Out of Our Shell: Expanding the Definition of Outreach in Academic Libraries." In Academic Library Outreach: Beyond the Campus Walls, edited by Nancy Courtney. Westport, CT: Libraries Unlimited.

Crowe, Kathryn. 2015. "Libraries and Student Success: A Campus Collaboration with High Impact Educational Practices." Proceedings of the Association of College and Research Libraries National Conference, Portland, OR.

Dewey, John. 1927. The Public and Its Problems. New York: Holt.

Driscoll, Amy. 2006. “The Benchmarking Potential of the New Carnegie Classification: Community Engagement." Campus Compact. http://compact.org/resource-posts/the-benchmarking-potential-of-the-new -carnegie-classification-community-engagement/4257.

Ehrlich, Thomas. 2000. Civic Responsibility and Higher Education. Phoenix, AZ: Oryx.

Faiks, Angi Herold. 2002. "Libraries and Extension: Engaging in Partnerships." Journal of Agricultural and Food Information 4 (3): 21-27.

Finks, Lee W. 1989. "Values without Shame." American Libraries 20 (4): 352-56.

Finley, Ashley. 2012. A Brief Review of the Evidence on Civic Learning in Higher Education. http://www.aacu.org /sites/default/files/files/crucible/CivicOutcomesBrief.pdf.

Franklin, Brinley. 2012. "Surviving to Thriving: Advancing the Institutional Mission." Journal of Library Administration $52(1)$ : 94-107.

Gehner, John. 2010. "Libraries, Low-Income People, and Social Exclusion.” Public Library Quarterly 29 (1): 39-47.

Gorman, Michael. 2000. Our Enduring Values: Librarianship in the 21st Century. Chicago: American Library Association.

Hall, Susan A. 2012. "Embedded Literary Programs within a First-Year Service Learning Course: Opportunities for Library Outreach and Instruction." Codex 1 (4): 27-36.

Hatcher, Julie Adele. 2008. "The Public Role of Professionals: Developing and Evaluating the Civic-Minded Professional Scale." PhD diss., Indiana University.

Heiselt, April K., and Robert E. Wolverton. 2009. "Libraries: Partners in Linking College Students and Their Communities through Service Learning.” Reference and User Services Quarterly 49 (1): 83-90.

Herther, Nancy K. 2008. "Service Learning and Engagement in the Academic Library: Operating out of the Box." College and Research Libraries News 69 (7): 386-89.

Kranich, Nancy. 2000. "Libraries: The Cornerstone of Democracy." American Libraries 31 (7): 5. 
Kranich, Nancy, Megan Lotts, and Gene Springs. 2014. "The Promise of Academic Libraries: Turning Outward to Transform Campus Communities." College and Research Libraries News 75 (4): 182-86.

Kranich, Nancy, Michele Reid, and Taylor Willingham. 2004. "Civic Engagement in Academic Libraries: Encouraging Active Citizenship." College and Research Libraries News 65 (7): 380-83, 388.

Kuh, George D., and Robert M. Gonyea. 2015. "The Role of the Academic Library in Promoting Student Engagement in Learning." College and Research Libraries News 76 (3): 359-85.

McCabe, Ronald B. 2001. Civic Librarianship: Renewing the Social Mission of the Public Library. Lanham, MD: Scarecrow.

McCook, Kathleen de la Pena. 2000. A Place at the Table: Participating in Community Building. Chicago: American Library Association.

Morris, Jen. 2013. "Free to Learn: Helping Ex-offenders with Reentry." Public Library Quarterly 32 (2): $119-23$.

Murray, Adam. 2015. “Academic Libraries and High-Impact Practices for Student Retention: Library Deans' Perspectives." Portal: Libraries and the Academy 15 (3): 471-87.

National Commission on Civic Renewal. 1997. "A Nation of Spectators: How Civic Disengagement Weakens America and What We Can Do about It. Final Report of the National Commission on Civic Renewal." http://www.puaf.umd.edu/civicrenewal.

National Task Force on Civic Learning and Democratic Engagement. 2012. "A Crucible Moment: College Learning and Democracy's Future." https://www.aacu.org/crucible.

Nichols Hess, Amanda, Katie Greer, Shawn V. Lombardo, and Adriene Lim. 2015. "Books, Bytes, and Buildings: The Academic Library's Unique Role in Improving Student Success.” Journal of Library Administration 55 (8): $622-38$.

Nutefall, Jennifer E. 2009. “The Relationship between Service Learning and Research.” Public Services Quarterly 5 (4): 250-61.

Oakleaf, Megan. 2010. The Value of Academic Libraries: A Comprehensive Research Review and Report. Chicago: Association of College and Research Libraries.

Oakleaf, Megan. 2015. "The Library's Contribution to Student Learning: Inspirations and Aspirations." College and Research Libraries News 76 (3): 353-58.

Raber, Douglas. 2007. "ACONDA and ANACONDA: Social Change, Social Responsibility, and Librarianship." Library Trends 55 (3): 675-97.

Riddle, John S. 2003. "Where's the Library in Service Learning? Models for Engaged Library Instruction." Journal of Academic Librarianship 29 (2): 71-81.

Salinero, David, and Cynthia Beardsley. 2009. "Enhancing the Academic Experience: The Library and Campus Engagement." College and Research Libraries News 70 (3): 150-52.

Schull, Diantha, 2004. "The Civic Library: A Model for 21st Century Participation." Advances in Librarianship 28:55-81.

Scull, Amanda. 2014. "Fostering Student Engagement and Collaboration with the Library: Student Creation of LibGuides as a Research Assignment." Reference Librarian 55 (4): 318-27.

Shuler, John. 2007. "The Civic Value of Academic Libraries and the Open Source University." Journal of Academic Librarianship 33 (2): 301-03.

Snavely, Loanne. 2012. Student Engagement and the Academic Library. Santa Barbara, CA: Libraries Unlimited. Tocqueville, Alexis de. 2012. Democracy in America: In Two Volumes. Indianapolis, IN: Liberty Fund.

Twill, Sarah, and Laura A. Lowe. 2014. "Social Workers as Civic-Minded Professionals." Advances in Social Work 15 (2): 278-93. 
Vander Broek, Jamie L., and Emily P. Rodgers. 2015. "Better Together: Responsive Community Programming at the U-M Library." Journal of Library Administration 55 (2): 131-41.

Westney, Lynn. 2006. "Conspicuous by Their Absence: Academic Librarians in the Engaged University." Reference and User Services Quarterly 45 (3): 200-03.

Maureen Barry: first-year experience librarian, Wright State University, Dayton, Ohio. Barry, MLS, has been employed by Wright State University for 10 years. Her research interests include civic engagement and service learning and how they relate to information literacy, libraries, and librarians. She has presented at several local, regional, and national conferences and written a few book chapters on these topics. She also moderates the Service Learning Librarian blog. E-mail: maureen.barry@wright.edu.

Laura A. Lowe: bachelor of social work program director and associate professor of social work, Texas Tech University, Lubbock, Texas. Prior to her employment as a social work educator, Lowe, PhD, LCSW, practiced social work in the community in the areas of juvenile corrections, developmental disability, domestic violence and sexual assault, and public housing. Her current practice and research interests are primarily in social work education as well as poverty and health care. E-mail (corresponding author): laura.lowe@ttu.edu.

Sarah Twill: professor and chair of social work at Wright State University, Dayton, Ohio. Prior to becoming a faculty member, Twill, PhD, MSW, was a practicing social worker. She worked as a mental health therapist and a juvenile probation officer and was the assistant director of a poverty outreach center. Her research interests include juvenile justice sentencing and treatment, and student success. E-mail: sarah.twill@wright.edu. 